\title{
PERBANDINGAN IDEOLOGI PADA NOVEL 'AZRA’ JAKARTA DENGAN IMAGOLOGIE SEJARAH G30S-PKI VERSI PERPUSTAKAAN NASIONAL
}

\author{
Nia Hailiyati
}

niahay20@gmail.com

\begin{abstract}
This paper aims to analyze the comparison of ideologies in the novel Azra 'Jakarta with the history of the G30 S / PKI version of the national library, the research data is the azra' Jakarta novel written by Najib Kaelani and the G30 S / PKI history of the national library, data analyzed by descriptive method with a comparative approach, while the technique of collecting data through library studies by capturing written data through the azra novel 'Jakarta and history book G30 S / PKI. Based on the results of the analysis, found the ideology that was built by Najib Kaelani in the novel is from the religious aspect, namely (anti-god for leaders, Islamic values, namely as a balance between the oppression of Muslims against politics, oppression of Muslims), while in terms of politics kidnapping state dignitaries, the ideology contained in the history of the National version of the G30 S / PKI, namely changes to the Pancasila, the religious aspect of the Pancasila is a spirit of tolerance that comes from Allah's power, PKI's tactic aspect that affects poor farmers, PKI rebellion, PKI infiltration into the ranks of the state apparatus, the interrelationship between Azra 'Jakarta by Najib Kaelani and the history of the G30 S / PKI version of the national library are both Islamic values based on humanity and social justice, there are similarities in the events of the authors with Indonesian history, assumed Najib learn to as far as Indonesia is concerned, in terms of religion, the country of origin of the mayor of Islam, as well as Indonesia, there is political engagement with the leaders of the two countries (Egypt and Indonesia)
\end{abstract}

\section{Keywords: Ideology, Imagologie, Azra 'Jakarta}

Abstrak: Tulisan ini bertujuan untuk menganalisis perbandingan ideologi pada novel Azra' Jakarta dengan sejarah G30 S/ PKI versi perpustakaan nasional, data penenlitian adalah novel azra' Jakarta yang di tulis oleh Najib Kaelani dan sejarah G30 S/ PKI versi perpustakaan nasional, data dianalisis dengan metode deskriptif dengan pendekatan perbandingan, sedangkan teknik pengumpulan data melalui studi pustaka dengan cara menjaring data tertulis melalui novel azra' Jakarta dan buku sejarah G30 S/PKI. Berdasarkan hasil analisis, ditemukan ideologi yang dibangun oleh Najib Kaelani dalam novel adalah dari segi keagamaan, yakni (anti tuhan bagi pemimpin, nilai-nilai keislaman, yakni sebagai penyeimbangan antara ketertindasan kaum muslimin terhadap politik, penindasan terhadap kaum muslim), adapun dari segi politik menculik para pembesar negara, ideologi yang terdapat dalam sejarah G30 S/PKI versi Nasional aspek ketuhanan, yakni perubahan terhadap pancasila, aspek agama yakni pancasila adalah semangat toleransi yang bersumber pada kekuasaan Allah, aspek siasat PKI yakni mempengaruhi petani miskin, peberontakan PKI, penyusupan PKI kedalam jajaran aparatur negara, keterkaitan antaranovel Azra' Jakarta karangan Najib Kaelani dengan sejarah G30 S /PKI versi perpustakaan nasional adalah kedua-duanya terdapat nilai keIslaman yang berdasar kemanusiaan dan keadilan sosial, adanya kesamaan peristiwa yang terjadi ditempat si pengarang dengan sejarah Indonesia, diasumsikan Najib mempelajari kesejarahan Indonesi, segi keagamaan, negara asal pengarang mayorita Islam, begitu juga Indonesia, adnya akedekatan politik dengan pemimpin terhadap dua negara (Mesir dan Indonesia)

Katakunci :Ideologi, Imagologie, Azra' Jakarta

\section{A. PENDAHULUAN}

Salah satu sejarah terpenting dalam perjalanan bangsa Indonesia yang tidak terlupakan adalah Gerakan 30 Sepetember/Partai Komunis Indonesia atau G30S/PKI yang terjadi di 
penghujung tahun 1965 adalah ideologi komunis yang berusaha utuk masuk ke dalam tubuh bangsa ini meninggalkan luka dan trauma berkepanjangan. Sayangnya peristiwa sejarah G30S/PKI 1965 ternyata tidak banyak para sastrawan menaruh perhatian besar pada kejadian sejarah ini untuk dijadikan sebagai bahan dalam penulisan karya sastra berupa novel, cerpen dan sebagainya. Dalam kondisi kekosongan ini, hadirnya sastrawan Mesir Najib Kaelani berusaha menggambarkan kejadian penindasan yang terjadi pada masyarakat Indonesiam pada tahun 1965 dalam novelnya yang berjudul " $A z r a$ ' Jakarta" dalam bahasa Indonesianya Gadis Jakarta, najib Kaelani menggambarkan peristiwa yang suram pada kejadian G30S/PKI, keunikan penulisan karya ini bukan hanya sekedar penulisnya yang bukan orang Indonesia yang sebelum kayanya diselesaikan tidak pernah menyaksikan G30S/PKI dan bahkan belum pernah mengunjungi Indonesia. Ini adalah nove satu-satunya yang mengangkat korban PKI dari sudut pandang orang Islam yang menjadi korban keganasan PKI. Sebagai karya sastra yang berbicara tentang sejarah ia mempunyai kemiripan dengan peristiwa dimana sejarah itu terjadi, yaitu dengan gambaran sejarah Indonesia.

Berdasarkan dari latar belakang tersebut, tulisan ini bertujuan untuk mengkaji, pertama, bagaimana ideologi yang digambarkan oleh Najib Kaelani dalam novel 'Azra' Jakarta, yang kedua bagaimana gambaran ideologi yang ditampilkan dalam sejarah Indonesia terhadap masyarakat muslim pada sejarah G30S/PKI, yang ketiga, bagaimana katerkaitan antara novel 'Azra' Jakarta dengan sejarah G30S/PKI dalam ideologinya terhadap kaum muslim. Tujuan dari tulisan ini adalah pertama untuk mengetahu bagaimana digambarkan oleh Najib Kaelani dalam novel 'Azra' Jakarta, yang kedua, unruk mengetahui bagaimana gambaran ideologi yang ditampilkan dalam sejarah Indonesia terhadap masyarakat muslim pada sejarah G30S/PKI, yang ketiga, untuk mengetahui bagaimana katerkaitan antara novel 'Azra' Jakarta dengan sejarah G30S/PKI dalam ideologinya terhadap kaum muslim.

\section{B. Metodologi / Pndekatan Penelitian}

Adapun dalam penelitian ini metode yang digunakan adalah adab muqaran atau sastra banding dan pendekatan deskriptif. Kajian sastra banding digunakan karena penelitian ini bertujuan untuk menemukan keterkaitan anatara dua karya sastra, yaitu novel 'Azra' Jakarta karya Najib Kaelani dengan sejarah G30S/PKI di Indonesia, pendekatan Deskriptif digunakan untuk mendeskripsikan bagaimana gambaran ideologi terhadap kaum Muslim dalam novel 'Azra' Jakarta dengan sejarah G30S/PKI.

\section{Kajian Teori}

Kajian pengaruh dan mempengaruhi dunia sastra merupakan hal yang wajar. Adanya kesamaan tema, gaya, maupun bentuk kedua karya sastra bisa jadi akibat dari pengaruh karya sastra yang terhadap karya sastra yang lain.tetpi tidak harus mutlak demikian. Dalam kajian perbandingan, selain membandingkan antara dua karya sastra, baik itu dari aspek intrinsik maupun ekstrensik,

1. Pengaruh karya sastra terhadap eksistensialisme (pemikiran Barat dalam sastra Arab), yaitu diterima oleh banyak negara, karena itu membahas masalah eksistensial kemanusiaan, seperti permasalahan kehidupam kematian, dll. ${ }^{1}$

2. Pengaruh karya sastra pada imagologie,

Imagologie adalah ilmu yang mengjkaji gambaran sastra, ${ }^{2} Y a i t u$ faktor pengaruh terhadap sejarah dan faktor individu ini adalah langkah 
yang kita ikuti dalam kajian Amerika pada studi perbandingan. ${ }^{3}$

\section{Pemikiran Najib Kaelani}

Kontribusi dan peran Najib Kaelani dalam dunia sastra adalah sebagai berikut :4

Najib al-KailanSastrawan ulung dari Mesir. Ia adalah salah satu pelopor sastra dan teater Islam. Karya-karyanya sarat nilai Islam dan kemanusiaan. Karya-karyanya sarat dengan kritik sosial. Berbilang kali ia masuk penjara. Dan justru dalam penjaralah karya-karya besarnya lahir. Bermacam penghargaan ia peroleh. Ia telah berhasil berdakwah dengan karya sastra. Berdakwah dengan novel. Najib Kailani adalah seorang novelis legendaris.Ia pengarang sangat produktif.

Kritik sosial dalam tulisan Najib sangat kental. Terutama pembelaan terhadap para kaum lemah, miskin, dan tertindas. Ia dikenal berani melawan rezim kezhaliman dan kebatilan. Tanpa melupakan dimensi religius yang cukup menonjol. Ia juga tak segan mengangkat tema tentang ulama dan cendekiawan. Ia mengkritik semua yang bertentangan dengan nilai Islam dan kemanusiaan.

Ketika terjadi Perang Dunia II, Mesir terkena dampak buruknya, termasuk kampung kelahirannya. Mesir dihantam krisis ekonomi hebat ditambah dengan tekanan dan penindasan penjajah Inggris. Para petani mengalami berbagai penderitaan. Najib Kailani lahir dan besar dalam situasi krisis politik dan ekonomi yang demikian buruk di Mesir.

Pada tahun 1955, Najib Kailani diajukan ke pengadilan, berkaitan kegiatannya politiknya yang aktif dalam gerakan Ikhwanul Muslimin. Tulisan-tulisan Najib sangat unik dan menarik. Kar-yanya lahir dari penghayatan mendalam terhadap nilai-nilai kemanusiaan, persaudaraan dan cinta. Karyanya lahir dari himpitan dan tekanan kezaliman, terutama berbagai bentuk penyiksaan dan intimidasi di penjara. Semuanya ia tuangkan dalam lebih dari 50 buku, berupa novel, kumpulan cerpen, kumpulan puisi, dan naskah drama. Selain itu, ia tuangkan juga dalam ratusan artikel ilmiyah yang tersebar di berbagai majalah dan surat kabar.

Dalam hampir keseluruhan karyanya, Najib selalu menyelipkan nilai-nilai Islam yang berdimensi kemanusiaan dan keadilan, serta menentang segala bentuk kezaliman, penindasan dan segala sesuatu yang bertentangan dengan ruh Islam. Nilai-nilai Islam dan kemanusiaan selalu menjadi lentera dalam karya-karyanya. Oleh karena itulah, Najib Kailani dikenal sebagai sastrawan pelopor dakwah bil novel. Bagi Najib, berdakwah tidak hanya di masjid, musholla dan majlis taklim dan temmpat lainnya. Berdakwah bisa lewat media karya sastra.

Najib tidak segan mengkritik profesi dokter yang bekerja hanya untuk mengeruk materi, tanpa memiliki misi kemanusiaan yang luhur. Ia juga selalu mengkritik orang yang menyandang gelar terhormat keagamaan justru melakukan tindakan yang menyimpang dari nilai-nilai Islam. Najib al-Kailani adalah teladan dan pelopor tentang bagaimana membangun karya sastra dengan sentuhan mendalam nilai Islam. Novel boleh saja bertema cinta, tapi tidak boleh lepas dari pesan moral dan kritik sosial. Yaitu pesan moral dan kritik sosial yang mencerahkan dan memajukan alam pikiran para pecinta dan penikmat karya sastra.

2. Sejarah komunis di Mesir

Zeonis tujuannya adalah menciptakan negara Israel yang kuat dan mampu mendominasi wilayah lewat berbagai cara, secara langsung 
ataupun tidak. Mereka memecah belah dunia Arab menjadi negaranegara kecil yang lemahberdasarkan ras, agama, dan kebangsaan. dengan demikain, Israelmemiliki dalih untuk berdiri sebagai sebuah negara yang juga berdasarkan prinsip keagamaan dan kebangsaan. ${ }^{5}$

Program ini disusun berdasarkan keyakinan bahwa nengara Arab adalah rumah dari tanah yang mudah dirobohkan. Negara ini terdiri atas kelompok-kelompok minoritas yang saling bertikai, baik dalam masalah ras, maupun keagamaan. Contohnya adalah Mesir. Mereka mengharapkan keruntuhannya karena negara ini inbarat perisai yang menghambat segala sepak terjangnya. ${ }^{6}$

Perlu juga disebutkan program borjonski, seorang penasihat keamanan nasional Amerika. Program ini terpusat pada pembagian negara Arab menjadi wilayat-wilayah sektoral untuk mewujudkan dominasi Amerika Israel diwilayah ini. ${ }^{7}$

\section{Kerja Sama Zionisme Dan Komunisme}

Kedua paham ini berasak dari satu rumpun, mereka senantiasa menjalin kerkja sama. Sesungguhnya zionisme dan komunisme adalah dua sisi dari satu mata uang. Sumbernya adalah paham free mansory. Sepanjang sejarah, zionisme selalu berusaha menjadikan komunisme sebagai alat mendominasi dunia. zionisme misinya adalah memerangi seluruh agama, khusunya Islam. Dengan runtuhnya ideologi itu. ${ }^{8}$

Bahaya zionisme lebih besar dari pada bahaya yang ditimbulkan oleh penjajahan. Sebab, zionisme disamping mencaplok wilayah pihak lain. Juga memerangi agama penduduk terjajah, menghancurkan aqidahnya, merampas hak-haknya dan merampas budi pekerti penduduknya. ${ }^{9}$

Sebagaian besar pendiri kaum komunis di Mesir adalah warga
Yahudi. Mereka sering menggunakan tipuan atau langkah-langkah rahasia dengan melakukan kegiatan yang tidak mencerminkan misi mereka, salah satu caranya adalah ada yang bekerja sebagai penerjemah koran. ${ }^{10}$

Freemansory mngirimkan mereka ke Mesir sebagai pembuka jalan untuk mendirikan agama negara Israel. Peristiwa komunis yang meletus di Mesir pada tahun 1925, juga melibatkan beberapa orang asing, sebagaian besar diantaranya adalah orang Yahudi jumlah organisasi yang didirikan orang Yahudi di negara ini lebih dari lima puluh. Organisasi-organisasi itu berperan dalam masalah Palestina. Mereka melibatkan mesir dalam perang Palestina demi keuntungan mereka. ${ }^{11}$

Hendri Kodlt berperan penting dalam melahirkan partai komunis terbesar dan terkenal dalam sejarah Mesir modern, yaitu gerakan pembebasan negara (Hadato). salah seorang anggotanya adalah Gamal Abdul Nasir, anggota gerakan 23 Juli 1952 yang berhasil menjatuhkan raja Farouk. ${ }^{12}$

Komunisme berhasil merebut kekuasaan dengan memerangi paham ketuhanan, sementara pihak barat berkuasa lewat jalan sekularisme. Nama-nama yang bernasfaskan Islam yang terdapat pada tempat tempat tertentu tidak lain hanyalah kedok untuk menutupi wajah para pemimpin komunis Timur dan pemimpin sekuler Barat . unsir-unsur Yahudi atau unsur-unsur hasil didikan Yahudi senantiasa berusaha menguasai umat Islam, secara langsung ataupun tidak. Mereka yang belajar di sekolah-sekolah Perancis di bawah bimbingan partai komunis Perancis, kemudian dikirim ke Mesir untuk membantu kaum komunis. ${ }^{13}$

\section{Sejarah Komunis di Indonesia}

Di Indonesia, upaya penyebaran paham komunisme dan materialisme 
dan PKI dengan menyusuk keberbagai elemen masyarakat. Institusi pemerintah , dan partai politik. Diantara partai politik besar di Indonesia hany berhasil disusupi PKI adalah sarekat Islam (SI) partai nasional Indonesia (PNI) dan partai Indonesia (Partindo). Penyusupan juga terjadi di dilembaga-lembaga pers dan media massa, seperti LKBN(lembaga kantor berita nasional) antara, PWI (persatuan wartawan Indonesia). Organisasi ikatan pelajar Indonesia terbesar di Indonesia juga disusupi dan dipecah belah.

Adapun tentang kudeta pada tahun 1965 dan malam pembunuhan terhadap Jendral telah menjadi sejarah. Pembunuhan para jendral yang di laksanakan oleh oknumoknum pasukan Cakrabirawa yang telah disusupi PKI. Adapun rumah pertama adalah kediaman Letjen Ahmad Yani. Ia menolak unytuk ikut pemaksaan tersebut, bila tidak ada surat perintah dari presiden, akibatnya pasukan Cakrabirawa menembak Letjen Ahmad Yani singga tewas. Selain jenral Ahmad Yani terjadi juga pada A.H Nasution, namun ia berhasil kabur setelah meloncat kedalam pagar kedutaan Irak dibelakang rumahnya, sementara anaknya Ade Irma Yani, ditembak 3 peluru yang membuat dirinya meninggal. ${ }^{14}$

Di bidang ideologi PKI, melancarkan upaya, perubahan yang mendasar terhadap pancasila, PKI berusaha mengganti sila pertama, yaki "Ketuhanan Yang Maha Esa" dengan rumusan "kemerdekaabn beragama" seperti yang telah dikemukakan oleh Njoto dalam sidang-sidang kontituante pada tahun 1958. Menurut PKI tidak senua masyarakat Indonesia beragama monotheis, banyak diantaranya yang beragama politheis, bahkan ada yang tidak beragama sama sekali. Jelas bahwa sejak semula PKI sudah berusaha untuk mengganti pancasila dengan paham lain. ${ }^{15}$

Njoto bahkan menyerang pernyataan golongan Islam, bahwa pancasila adalah semangat toleransi yang bersumber pada kekuasaan Allah sebagai punggung dari pokokpokok pancasila, dari pendapat tokoh PKI itu, jelas bahwa PKI menerima pancasila hanya sebgai alat pemersatu saja, sedangkan tujuan akhir menurut PKI adalah mewujudkan masyarakat komunis di Indonesia. 16

PKI tidak berhasil melakukan penyusupan ke dalm partai-partai yang yang berdasaekan agama, walaupun demikian praktis PKI telah mampu menetralisir perlawanan dari partai-partai politik yang berdasarkan agama. ${ }^{17}$

\section{Peristiwa Kanigoro Kediri}

3000 massa anggota PKI yang dipimpin oeh ketua cabang pemuda pengurus rakyat daerah kediri, Soejardi, mengadakan teror dengan melakukan penyerbuan terhadap para aktivis pelakar Islam Indonesia (PPI) yqng sedanag mengadkan mental training (pelatohan mental), PKI melakukan pemukulan dan penganiayaan terhadap para kiai dan imam masjid sera merusak rumah ibadah, bahkan menginjak kitabkitab suci al-Qur'an. ${ }^{18}$

Selain jendral tersebut di atas, kejadian tersebut juga dialami oleh Mayjen TNI Harjono MT dan Brigjen TNI D.I Panjaiatan. Mereka tewas karena tidak menuruti perintah PKI dan Mayjen TNI Sopeprapto, Mayjen TNI S. Parman, Mayjen TNI Soetojo S dibawa hidup-hidup ke markas pelatihan anak organisasi PKI di halim perdaka Kusumah unruk diesekusi secara sadis.

\section{Analisis dan hasil}

\section{Ideologi dalam Novel Azra' Jakarta}


Berdasarkan dari penyajian novel ini, adapun konsep atau ideologi yang ingin disampaikan oleh Najib Kaelani adalah hal-hal yang berkaitan dengan konsep pemikirannya, baik itu dari segi agama, maupun perpolitikan yang telah menjadi tujuan dari dakwah yang dilakukannya dalam novel.

a. Keagamaan

1) Anti tuhan

Berdasarkan dari kutipan dalam novel ini bahwa, ada pernyataan anti tuhan bagi Zaim (pemimpin partai),

اقتربت منه ( زوجته )ورتتت على كتافه فى حنان

وقالت : أنت تهذى...كفى كلاما ....لم يكترث

لها , بل انطلق يتكلم: (وحول العبشرون أن

يسيطروا على عقلى ليحولونى إلى الديانة المسيحية

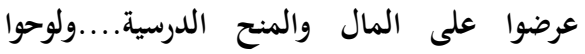

بفتيات جميلات كالورود اليانعة ...زعموا أن

الاعتراف أمام (الأدب المقدس ) يمحو الذنوب

آ هـ هذا عصر الفلسفات الكثيرة ..زإن رأسى ل. . . .

يدور ..السعيد فى هذه الحياة هو الحيوان لن يبعثه

الله ولن يحسبه تمنية فى أوقات كثيرة أن حيوانا

بلادنا يطحنها للشقات). 19

"para missionaris berusaha mepengaruhi pemikiranku, mereka menghendaki akum masuk agama Kristen dengan menawarkan harta dan pekerjaan akademik. Mereka menyangka pengakuan dosa dihadapan "Tuhan Bapa Yang Suci" akan menghapus dosa, betapa banyak aliran filsafat yang membuat kepalaku pusing. Pada jaman sekarang yang paling bahagia dalah binatang, Allah kelak tidak akan membangkitkan dan dan menghisab binatang. kadang-kadang aku ingin menjadi binatang".

Kaum partai ini beranggapan jika mereka mempercayai tuhan, itu merupakan penghambat dalam memajukan bangsa, sebagaimana tujuan kaum komunis adalah merebut kekuasaan dengan memerangi paham ketuhanan. Kaum komunis atau partai ini menyatakan diri meraka Islam, namun mereka memerangi ajaran Islam dengan berbadai cara, seperti tuduhan, dll.

Penulis berasumsi bahwa yang ingin disampaikan oleh Najib ialah dari segi ketuhanan yaitu yang berhubungan dengan tujuannya dalam aliran novelnya, yaitu yang berasaskan pada agama, serta ketuhanan, itulah yang dilakukan komunis pada saat siasatnya sudah dimulai untuk mengubah paham ketuhanan pada suatu negara.

Selanjutnya tokoh dalam novel ini menanggap bahwa dirinya adalah tuhan yang dapat menguasai segalanya, sebagaimana yang tercantum berikut ini "

(افهمينى يا حبيبى , لوتناوبتك الشكوك هكذا

فى كل همرأة اقابلها فمعنى ذلك أن أعمال

للحذب ستتعطل نحن نسابقا الزمن ولا مجال

لتضييع الوقت يجب أن تدركى أنك زوجة زعيم النه ولا دجال

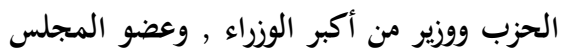

التأسيسى و, وعضو البرلمان , ونائب رئيس

المجلس الإستشارى الأعلى , والحامل الأعلى ولى ولى

وسام من أوسمة الدولة.

Aku akan menjadi salah seorang pahlawan terbesar kata AzZaim. Pulau kecil tempat kelahiranku, akan kuubah menjadi daerah kunjungan wisatawan. Akan kubuat isteri para jendral mejadi janda. para ulama akan kugembalakan seperti kambing. Aku akan memerintahkan jutaan manusia. Inilah orangnya yang ada dihadapanmu yang akan menjadi tuhan baru di negara ini, kata AzZaaim berapi-api". 
Komunis adalah kaum yang mengaggap bahwa tuhan tidak ada, dan kekuasaan itu berada ditangan manusia, oleh sebabb itu pemikiran Najib Kaelani sama persisnya dengan sejarah yang terjadi di Indonesi, ia ingin menyampaikan bahwa kejadian bahwa yang dilakukan komunis adalah menyimpang dari ajaran tuhan.

2) Nilai-nilai keislaman
Agama yang menjadi acuan dalam mencegah kezhaliman adalah agama Islam, oleh sebab dalam novel ini untuk menyeimbangkan antara tertidasan kaum muslim terhadap kaum politik adalah dengan adanya agama Islam, sebagaimana yang terdapat dalam novel, yaitu "Kedatangan Islam ditanah air kita ini adalah untuk mecegah kerusakan, kezalaiman dengan tradisi, fanatis dan paham keagamaan sempit, Islam menyeru hati manusia pada nilai-nilai luhur, agar mampu melahirkan peradaban. Inilah kenyataan yang tak terbantahkan pada sejarah masa lalu dan masa yang akan datang sebentar lagi".

3) Penindasan terhadap kaum muslim.

Penculikan
dilakukan oleh pang
terhadap ayah dan kekasih
fatimah yang menentang
ideologi atau gagasan dari
"partai". Karena ayah fatimah
adalah seorang anggota
masyumi ( masyumi adalah
kepanjangan dari majlis syura
muslimin Indonesia, semula
organisasi keagamaan,
kemudian menjadi partai
politik, yang mewadahi
aspirasi politik, seluruh umat

Islam sekaligus menjadi musuh utama PKI).

Berikut ini adalah

kutipan penindasan yang terdapat dalam novel ini "Perselisihan politik pada akhirnya hanya menimbulkan kekejaman dan kekerasan, dan alangkah rusaknya negara kita, jika terus menerus menjadi pertumpahan darah. "Abu Hasan kembali berkata, saya kira posisi umat Islam sangat lemah. umat Islam yang banyak hanya menjadi sasaran perilaku sewenang-wenang para pemimpin. Para pemimpin digerakkan oleh benang-benang tersembunyi". Inilah yang dilakukan kaum komunis pada masyarakat muslim indonesia. Kaum komunis penyebab terjadinya krisis pada suatu negara adalah agama.

Sebagaimana paham marxisme, yaitu berusaha melakukan upaya lain untuk menumpas agama, namun menemui kegagalan, ini menggucangkan kubu mereka sehingga mereka sepakat untuk meninjau kembali usaha atheis atau pemurtadan umat manusia, semula mereka menganggap bahwa agama bisa ditumpas dengan segera, ketika telah bermunculan generasi baru yang beriman kepada Allah, memilki kebudayaan keilmuan yang tinggi, dan memahami agama secara mendalam. ${ }^{21}$

b. Politik

Menculik oang yang berpengaruh (pembesar) dalam negara yang menentang partai, adapun kutipan novelnya adalah “ 
فى اليوم المشؤم, أعطى الكلونيل قائد الحرس

الجمهورى إشارة البدء فى هندلاع الثورة , وقد كان

جهذ عدة مجموعات مكونة من الحرس و من جبهة

شباب الحزب وتسلل المتأمرين تخت جنح الظلام ..

هذا هو بيت قائد القوات البرية , والذى لفت الإنظار

بالأمس القريب إلى تسلح رجال الحزب وتدريبهم

واستعدادهم للقيام بحركة مخربة .. لابد من البدء به به بـ بـ

$$
\text { . . أنه عدو لدود للحزب.22 }
$$

Pada hari yang na'as, sang kolonel memberi perintah pada komandan pengawal istana untuk mulai menyalakan api revolusi. Ia telah menyiapkan masa dalam jumlah besar, yang terdiri dari anggota pasukan pengawal istana dan kelompok pemuda partai, intuk mencilik delapan jendral yang dikenal sebagai penentang utama partai. Oran-orang yang diperintahkan sudah mulai bergerak di bewah kegelapan malam. Dumulai dari rumah kepala staff angkatan darat. Ia adalah orang yang berapa waktu lalu meminta penundaan rencana mempersenjatai anggota partai. Operasi ini harus dimulai dari dirinya, sebab jendral ini adalah musuh utama yang sangat keras menentang keberadaan partai.

Tujuan dari komunis untuk menguasai daerahnya adalah dengan cara menindas atau melenyapkan orang-orang yang berpengaruh dalam suatu negara, yang dapat menghalangi rencananya. Maka dengan penculikan para jendral, maka jalan yang ingin dituju oleh komunis terbuka lebar. Diasumsikan inilah yang menjadi titik sama suatu kejadian yang dialami oleh Najib di Mesir dengan kejadian yang ada di Indonesia, sehingga Najib mengemukakan aspek penculikan dalam novelnya.

1) Menindas kaum yang lemah

2. Sejarah

G30S-PKI

Versi Perpustakaan Nasional

a. Aspek Ketuhanan
Di bidang ideologi PKI, melancarkan upaya, perubahan yang mendasar terhadap pancasila, PKI berusaha mengganti sila pertama, yaki "Ketuhanan Yang Maha Esa" dengan rumusan "kemerdekaabn beragama" seperti yang telah dikemukakan oleh Njoto dalam sidang-sidang kontituante pada tahun 1958. Menurut PKI tidak senua masyarakat Indonesia beragama monotheis, banyak diantaranya yang beragama politheis, bahkan ada yang tidak beragama sama sekali. Jelas bahwa sejak semula PKI sudah berusaha untuk mengganti pancasila dengan paham lain. ${ }^{23}$

b. Aspek Agama

Njoto bahkan menyerang pernyataan golongan Islam, bahwa pancasila adalah semangat toleransi yang bersumber pada kekuasaan Allah sebagai punggung dari pokokpokok pancasila, dari pendapat tokoh PKI itu, jelas bahwa PKI menerima pancasila hanya sebgai alat pemersatu saja, sedangkan tujuan akhir menurut PKI adalah mewujudkan masyarakat komunis di Indonesia. ${ }^{24}$

PKI tidak berhasil melakukan penyusupan ke dalam partaipartai yang yang berdasarkan agama, walaupun demikian praktisi PKI telah mampu menetralisir perlawanan dari partai-partai politik yang berdasarkan agama. ${ }^{25}$

c. Aspek Siasat PKI

Untuk dapat mempenagruhi kelompok petani miskin , PKI menggunakan dalih membela mereka, melakukan kampanye yang menuntut dilaksanakannya undang-undang perjanjian

d. Pemberontakan PKI 
Pemberontakan yang dilakukan oleh PKI di berbagai wilayah indonesia

e. Penyusupan PKI kedalam jajaran aparatur negara lainnya dan kedalam partai politik.

\section{Keterkaitan 'Azra' Jakarta karya Najib Kaelani dengan sejarah G30S/PKI}

Berdasarkan dari novel Najib Kaelani yang membuat karya novel yang berjudul 'Azra' Jakarta diasumsikan memiliki keterkaitan dengan sejarah G30SPKI (gerakan 30 Sptember Partai komunis Indonesia, walaupin Najib Kaelani sebenarnya tidak pernah mengunjungi Indonesia dalam menyusun novel tersebut. Walaupun demikin ini tidak menjadi pengahalang bagi seorang sastrawan dalam membuat karya sastra yang berlatar sejarah. diasumsikan bahwa dalam novel ini memiliki keterkaitanitu berdasarkan :

1. Kecenderungan pemikiran Najib berdakwah dengan novel,menyelipkan nilai keIslaman yang berasaskan kemanusiaan dan keadilan sosial, serta menghindari atau menjauhi kezaliman, penindasan dan segala sesuatu yang bertentangan dengan ruh Islam. Inilaah yang disampaikan oleh Najib kaelani, begitu juga dengan sejarah Indonesia, banyak korban dari kekerasan komunis adalah orang muslim. Pesan yang disampaikan oleh Najib, mengandung nilai-nilai Islam

2. Berdasarkan latar belakang kehidupan Najib Kaelani dengan sejarah komunis Indonesia, dia mengalami kekrisisan ekonomi dan kekerasan pada saat terjadinya perlakuan komunis di Mesir, yang mendorong Najib untuk membuat karya sastra yang berlatar belakang yang sama, sebagaimana yang terjadi di Indonesia. Dengan adanya persamaan dalam segi perlakuan komunis maka Najib menggunakan sejarah yang hampir sama dengan karya sastranya.

3. Diasumsikan Najib Kaelani memang membaca/ mempelajari kisah-kisah kekerasan yang terjadi di Indonesia pada sejarah G30S/PKI,

4. Mesir mayoritas nya Islam dan Indonesia adalah mayoritasnya juga Islam,oleh sebab itu adanya kesamaan dari segi agama menbuat Najib memilih sejarah Indonesia dalam A'zra' Jakarta.

5. Adanya kedekatan politik, yaitu Indonesia dipimpin oleh Seokarno (yang dekat dengan PKI), Kedekatan Mesir dipimpin oleh pemimpin yang sama dalam bentuk pemerintahannya, yang pemimpinya dengan Abdul Nasr di Mesir.

\section{Kesimpulan}

Antara Azra' Jakarta dan sejarah G30S/PKI yang ada di Indonesia memiliki keterkaitan, yaitu adanya hubungan pengaruh dari sejarah G30S/PKI dengan novel Azra' Jakarta, diantaranya, adanya ideologi dari novel Najib kaelani yang sama dengan tindakan yang dilakukan oleh komunis di Indonesia, yaitu banyaknya korban dari komunis itu berasal dari muslim.

Adanya latar belakang kehidupan yang sama, yang mengakibatkan novel ini bisa dibuat dengan kemiripan sejarah komunis di Mesir. Inilah yang menjadi titik temu antara ideologi tang ditamilkan oleh Najib Kaelani dengan sejarah G30/SPKI di Indonesia.

\section{Referensi}

1 Majdah Hamud, Muqarrabat Tatbiquyah fil Adab al-Muqarran, www..awu-dam.com, 2000, hlm. 86

2Ibid, hlm.109

3Ibid, hlm. 7 
${ }^{4}$ Http:/ / www.suaramuhammadiyah.id/2016/ 02/17/najib-kailani-pelopor-dakwah-bilnovel/

${ }^{5}$ Anwar Jundi, Islam Setelah Komunis, (Gema Insani Press : Jakarta, 1994), hlm. 126

${ }^{6}$ Ibid, hlm. 126

7Ibid, hlm. 127

8Ibid, hlm. 46

9 Ibid, hlm. 46

${ }^{10}$ Ibid, hlm. 47

11Ibid, hlm. 49-50

12Ibid, hlm. 50

${ }^{13} \mathrm{Ibid}, \mathrm{hlm} .50$

14Sekretariat Negara RI, Gerakan 30 September Pemberontakan PKI (Latar Belakang, Aksi, dan Penumpasannya), (Sekneg : Jakarta, 1994), hlm. 96-101

15Sekretariat Negara RI, Gerakan 30 September Pemberontakan PKI (Latar Belakang, Aksi, dan Penumpasannya), (Sekneg : Jakarta ,1994), hlm. 28

16Ibid, hlm.32

17Ibid, hlm.45

${ }^{18}$ Ibid, hlm.53

${ }^{19}$ Najib, Al-Kelani, 'Azra' Jakarta (Rajol), ( AlMutafarra'ah min Maidan, as-Saidah Zainab :

Kairo, 2005 ), cet. Ke 25, hlm. 10

20Ibid, hlm. 6-7

${ }^{21}$ Anwar Junadi, hlm. 121

22Ibid, hlm. 129

23Sekretariat Negara RI, Gerakan 30 September Pemberontakan PKI (Latar Belakang, Aksi, dan Penumpasannya), (Sekneg : Jakarta ,1994), hlm. 28

${ }^{24} \mathrm{Ibid}$, hlm.32

${ }^{25}$ Ibid, hlm.45

\section{Buku}

Hamud, Majdah, Muqarrabat Tatbiqiyah fil Adab al-Muqarran, www.awu-dam.com, 2000

Http:// www.suaramuhammadiyah .id/2016/02/17/najib-kailani-pelopordakwah-bil-novel/ diakses tanggal 25 Agustus 2018

Jundi, Anwar, Islam Setelah Komunis, Gema Insani Press : Jakarta, 1994

Sekretariat Negara RI, Gerakan 30 September Pemberontakan PKI (Latar Belakang, Aksi, dan Penumpasannya), Sekneg : Jakarta, 1994
Wira Subrata dan Kundan D. Nuryaqien. Jakarta : CV Cendekia Sentra Muslim.

Shafiyyah, Amatullah dan Haryati, Soeripno, 1999. Kiprah Politik Muslimah : Konsep dan Implementasinya. Jakarta : Gema Insani Press

Soekanto, Soerjono. 1982. Sosiologi Suatu Pengantar. Jakarta : CV Rajawali.

Surbakti, Ramlan. 1992. Memahami Ilmu Politik. Jakarta : Grasindo.

Tarbawi. 2003, Wanita Ilham dari Surga, Jakarta, PT Media Amal Tarbawi, edisi56, th 4-3 April

Takariawan, Cahyadi. 2002. Fikih Politik Kaum Perempuan, Yogyakarta : Tiga Lentera Utama.

Quraish. M. Shihab. 1999, Lentera Hati, Bandung : Mizan 